\title{
UNIVERSITYOF
}

FORWARD

THINKING

WESTMINSTER用

WestminsterResearch

http://www.westminster.ac.uk/westminsterresearch

The Spaces of Medieval Mystery Plays on British Television Wrigley, A.

Copyright $@ 2015$ John Hopkins University Press. This article first appeared in Shakespeare Bulletin 33 (4), pp. 569-593, 2015.

The final, definitive version is available from the publisher at:

https://doi.org/10.1353/shb.2015.0058

The WestminsterResearch online digital archive at the University of Westminster aims to make the research output of the University available to a wider audience. Copyright and Moral Rights remain with the authors and/or copyright owners.

Whilst further distribution of specific materials from within this archive is forbidden, you may freely distribute the URL of WestminsterResearch: ((http://westminsterresearch.wmin.ac.uk/)).

In case of abuse or copyright appearing without permission e-mail repository@westminster.ac.uk 


\section{The Spaces of Medieval Mystery Plays on British Television}

\section{AMANDA WRIGLEY \\ University of Westminster}

Medieval mystery plays have had a rich and also distinctive life on British television. These performance texts, drawn from the Bible's story of the universe from just before its Creation to its end on the Day of Judgment, have appealed to television practitioners not only for drama adaptations (from the 1938 presentation of the Chester Abraham and Isaac onwards) and the foundation stone for new dramatic writing (such as the BBC's 1959 The Hill by Paul Almond) but also as the focus of documentaries on contemporary civic, social and religious traditions within communities. Charles Parker, for example, cast his own mystery play from the people of York in a 1973 episode of BBC1's Omnibus, and the 2008 BBC1 Miracle on the Estate chronicled how a mystery play was made into a film by north Manchester residents. Indeed, because of television's interest in the rich web of meanings arising from and surrounding mystery play performance, especially with regard to their relationship with place and community, it is not always easy to make clear-cut distinctions between program genres-in particular, between programs that may be considered to be primarily dramatic productions of part or all of a mystery play and programs that contextualize dramatic performance within the overall form of documentary. The first recorded production of a mystery play in 1938 is itself described in Radio Times as a "reconstruction of the preparation and presentation" (Television Listings) of the Chester Abraham and Isaac, wording that strongly suggests that the program, titled Miracle at Chester, may have been part documentary ("preparation") and part performance ("presentation"), with both elements staged in the Alexandra Palace studios.

In 1938, Miracle at Chester was televised on the Sunday evening following Thursday's Feast of Corpus Christi. ${ }^{1}$ Two separate but related productions of The Coventry Nativity Play were broadcast on Christmas Eve in 1947 and 1949. Paul Almond's The Hill was transmitted on Good Friday in 1959. On Maundy Thursday 1960, The True Mistery of the Passion was broadcast from Bristol Cathedral (and a recording of the production was repeated on Good Friday 1961). The Wakefield Shepherds' Play was transmitted as the last in a drama series for schools on 28 November 1961, probably as close to Christmas as the schools broadcasting schedule allowed. On Easter Sunday 1976 The Chester Mystery Plays was offered in the Play of the Month strand. The Nativity, the first part of the National Theatre's three-part production of The Mysteries, was shown three days before Christmas Day 1985. The Manchester Passion was transmitted on Good Friday $2006 .^{2}$ What is clear from this extensive but not exhaustive list is that, throughout the history of television, both dramatic productions and documentaries were regularly, and indeed routinely, transmitted on or very close to significant and relevant dates in the Christian calendar, suggesting that they were perceived to contribute both value and variation to religious programming schedules. Yet this list, which includes many of the mystery plays known to have been performed on British television, also indicates what appears to be a unique case of a dramatic genre that existed in the programming schedules largely within and in relation to a particular cultural context 
within society more generally, and within and in relation to, in particular, the BBC's broadcasting commitment to observe significant dates in the Christian calendar. In other words, mystery plays were considered to make a valuable contribution to religious broadcasting but, it appears, they were not sufficiently interesting (or perhaps not regarded as sufficiently popular) to be broadcast as drama standing alone from the context of the Christian calendar. Furthermore, only occasionally were mystery plays produced and transmitted by television companies and networks other than the BBC. Producing mystery plays was a particularly BBC pursuit, aligned with the Corporation's extensive religious output grounded in Christianity. It may also be conjectured that the chronologically remote and dramaturgically challenging character of this form of drama meant that commercial television companies may have shied away from producing them for television, as they seem to a large extent to have done also with regard to the similarly remote and potentially challenging forms of Greek drama. ${ }^{3}$

Very little scholarly attention has been paid to British television's long series of engagements with mystery plays, which stands in contrast to the extensive scholarship about the modes and meanings of mystery plays in live performance during modern times. ${ }^{4}$ Both John R. Elliott and Katie Normington have explored the possible reasons underpinning the live performance of mystery plays in the twentieth and twenty-first centuries; those that may be relevant to television engagements with the plays include their religious content, an attempt to locate the contemporary relevance of religious drama and an exploration of community identity and pride. Bearing these possibilities in mind, this essay will consider the extent to which dramatic performances of mystery plays produced especially for television may have contributed to an understanding of this performance genre as a mode of expression related to religious, social, and civic traditions and community life in both medieval and modern Britain. This exploration will focus particularly on how the spaces of production (a studio, cathedral, street) and the spaces of performance constructed therein (a landscape or medieval images) evoke particular interpretative frames of reference, some of which are tied strongly to a sense of place- with places, and the communities that inhabit them, being fundamentally important dimensions of performances of mystery plays.

\section{Framing Performance in Medieval Art}

The first known full BBC television production of a mystery play was The Coventry Nativity Play, which was transmitted live from Alexandra Palace's Studio B at 9.15pm on Christmas Eve 1947. In an illustrated article published in the advance issue of the Radio Times on 19 December 1947, John Swift begins by outlining for the reader the various performance spaces that mystery plays have inhabited over the centuries, from churches, he says, to wagons, pageants, market squares, theaters, radio, and now, for the first time, television. He furnishes the reader with information about the various literary and production contexts of the plays in medieval times, emphasizing uncertainty on many points and concluding by saying that Douglas Allen, the producer of this nativity play, makes "no attempt to present it as it was in the past." Rather, Allen sets the performance "in a triptych with folding doors, like an Italian Primitive, keeping up the old accepted tradition of a three-sided stage, one for 
Nazareth, another for Herod's Court, and a third for Bethlehem. The general effect will be as if the illuminated pages of an old manuscript were brought to life."

In 1949, two years to the day later, a second production from the same script was mounted, with new sets and movement. 5 There is no movingimage record for either of these productions, but traces of how the play was presented on the small screen exist. The illustration accompanying the 1947 Radio Times article cited above shows four angels (two kneeling at center; two standing either side) before the triptych, the three panels of which are shaped as decorated arches with, typically, the central arch being the largest and most detailed. Two years later, an image of the same composition was printed by the Radio Times, but the triptych appears significantly bigger and more decorative than in the earlier illustration; and, instead of simple Bible scenes in the three panels (with the Crucifixion central), the backdrop for the whole image is a starry sky and what appears to be a perspectival checkered floor, with the frames of the triptych serving as "windows" onto this space. Detailed plans extant in the BBC's archive show how in both productions the triptych flats were constructed as a pair of double-hinged doors that opened down the center and folded outwards to create a double-width semi-circular backdrop. It appears from other production documents that most, if not all, action took place beyond the "frames" provided by the opened-up triptych, and that this was captured by three cameras (see BBC Written Archives Centre (WAC) T5/114).

Fig. 1. Production image of The Coventry Nativity Play (prod. Douglas Allen, 1949), printed in Radio Times, 23 December 1949 (45) to advertise a repeat broadcast on 29 December. Reproduced by permission of Immediate Media.

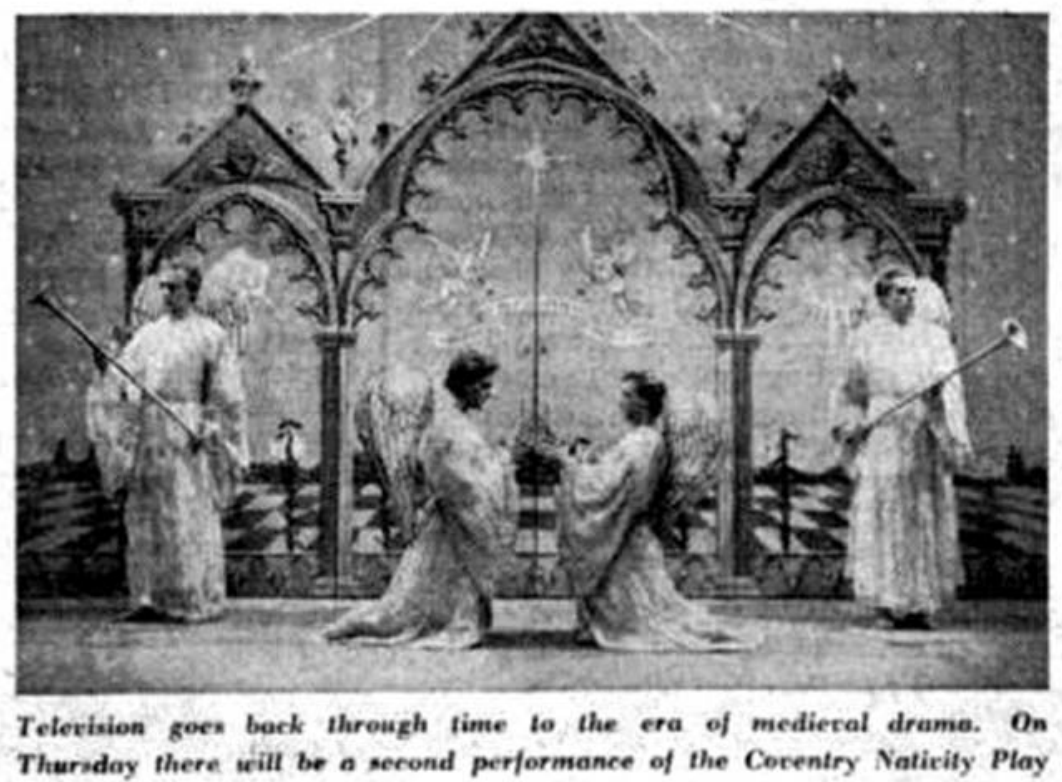

Studio plans note that a smaller second set at the other end of the studio was dressed as a cloister (using arches, pillars, and windows from 1947 television productions of Pirandello's Henry IV and T.S. Eliot's Murder in the Cathedral). ${ }^{6}$ Here, a single camera took in a medieval illuminator's high desk and bench. A handwritten account in an undated exercise book that appears to have belonged to Allen offers 
fascinating insights into the use of this smaller set to introduce and contextualize the nativity play performance for the viewer:

Short introduction given by narrator, in vision, towards end of which we mix to a long shot of a long dim cloister, at the further end of which a figure is seen in a shaft of sunlight. As the camera slowly tracks in down the cloister, we see that the figure is that of a monk, seated at a high illuminating desk. On this is a large leather bound volume. On the left hand page is a photograph of the closed triptych with four angels, made to look as much as possible like a painted illustration. On the right hand page, the monk is writing the first words of the nativity play- "Hail Mary. . ." The camera goes in as close as possible to the illustration. We then mix to a photographic caption of the same, and superimpose the "live" picture from the studio. Two angels are kneeling at the closed doors of the triptych, and one is standing at either side, each holding a long trumpet. Fan fares [sic]. The two outside angels raise their trumpets. The two kneeling ones ride, and open the two doors of the centre arch; revealing Mary seated on a stool, reading. Gabriel enters R[ight]. (BBC WAC $\mathrm{T} 5 / 114)^{7}$

At the end of the play, the camera tracks back to frame the whole tableau-Gabriel in the left arch, the kings and shepherds central and Herod on his throne in the right arch. Accompanied by a trumpet fanfare, the angels close the doors of the triptych and take up their original positions in front. This live image is then mixed with the mounted photograph of the same composition in the book being worked on by the monk, who writes the word "Finis" and in this way brings the presentation to an end.

The performance of this nativity play from medieval times is, therefore, set within a number of useful interpretative frames which may have been similar to the effect, as Meg Twycross and others have discussed, of the physical structure of medieval pageant wagons that, in turn, echoed the framed stories told in stained-glass windows or Books of Hours. The play is approached in the context of, first, a medieval manuscript and, then, via the triptych, medieval painting. The play is situated in a time far removed from the twentieth century, but it is also defined as something that may be approached and interpreted via other, roughly chronological, cultural forms with strong religious and visual dimensions (even if not directly related to mystery play performance). The device of a still picture "coming to life" is a relatively common one at the start of televised theater plays (and was used also between acts) but, given that the book that contains the picture in this example is in itself in the process of creation, there may have been the sense of the performance as a living product of the monk's imagination. Indeed, as referenced above, the Radio Times notes that it was as if "the illuminated pages of an old manuscript were brought to life" (Swift); or, as the 29 December 1949 repeat performance was introduced to the target audience of "older children, [. . .] We are presenting it as if it were illustrations from one of your picture books." 8 The visual arts also served as a crucially important inspiration for the design: the production file in the BBC archive contains several photographic reproductions from the Uffizi of paintings by Don Lorenzo Monaco (such as "Adorazione dei Magi"); and Allen's instruction to the former Ballets Russes dancer Lydia Sokolova, in charge of movement in 1949, was that her work should be inspired by groupings of figures in stained-glass window compositions. Setting the action of the play within the frame of the triptych avoided difficult staging decisions, but in doing so it circumvented engagement with original 
performance conditions and contexts of medieval England. There appears to have been no attempt at the realistic representation of space and, together with the amount of sung performance, the sense is of a performance that was strongly stylized-an adjective used by the television producer George More O'Ferrall to describe the production from attending rehearsals in $1947 . .^{9}$ The dominant space of this production is, therefore, the two-dimensional screen-and not as in other productions under discussion here, the studio, a church or an urban settingmeaning that the primary aesthetic in this particular performative engagement with medieval mystery plays was very much that of animated art.

The device of an illuminated manuscript serving as an imaginative entry point for the performance of mystery plays on television was used again almost three decades later in the 1976 production of The Chester Mystery Plays, transmitted in the BBC1 Play of the Month strand on Easter Sunday 18 April 1976 from 4.55pm.

Technological evolution-specifically, the technique of Colour Separation Overlay (CSO), whereby several images from different cameras are layered to create the final image-meant that, by this time, medieval art could be used not merely as the frame but as the aesthetic and compositional backbone of a production in a highly inventive and striking way. Directed by Piers Haggard and produced by Cedric Messina, this two-and-a-half-hour production offered an "electronic version of the Middle Ages." The CSO technique had been used in light entertainment for some time and in a handful of dramatic productions by the BBC (including Alice through the Looking-Glass, 1973) but it was still enough of a spectacular novelty, combined with the rarity of medieval drama on television, to warrant detailed exposition in the advance issue of the Radio Times. Not only did the magazine publish several images from the production, including one on the cover, but a two-page article included a color diagram (of cameras and individual screen-shots making up the resulting image) intended to explain this "extremely complex technology" to viewers (Mitchell 3). 


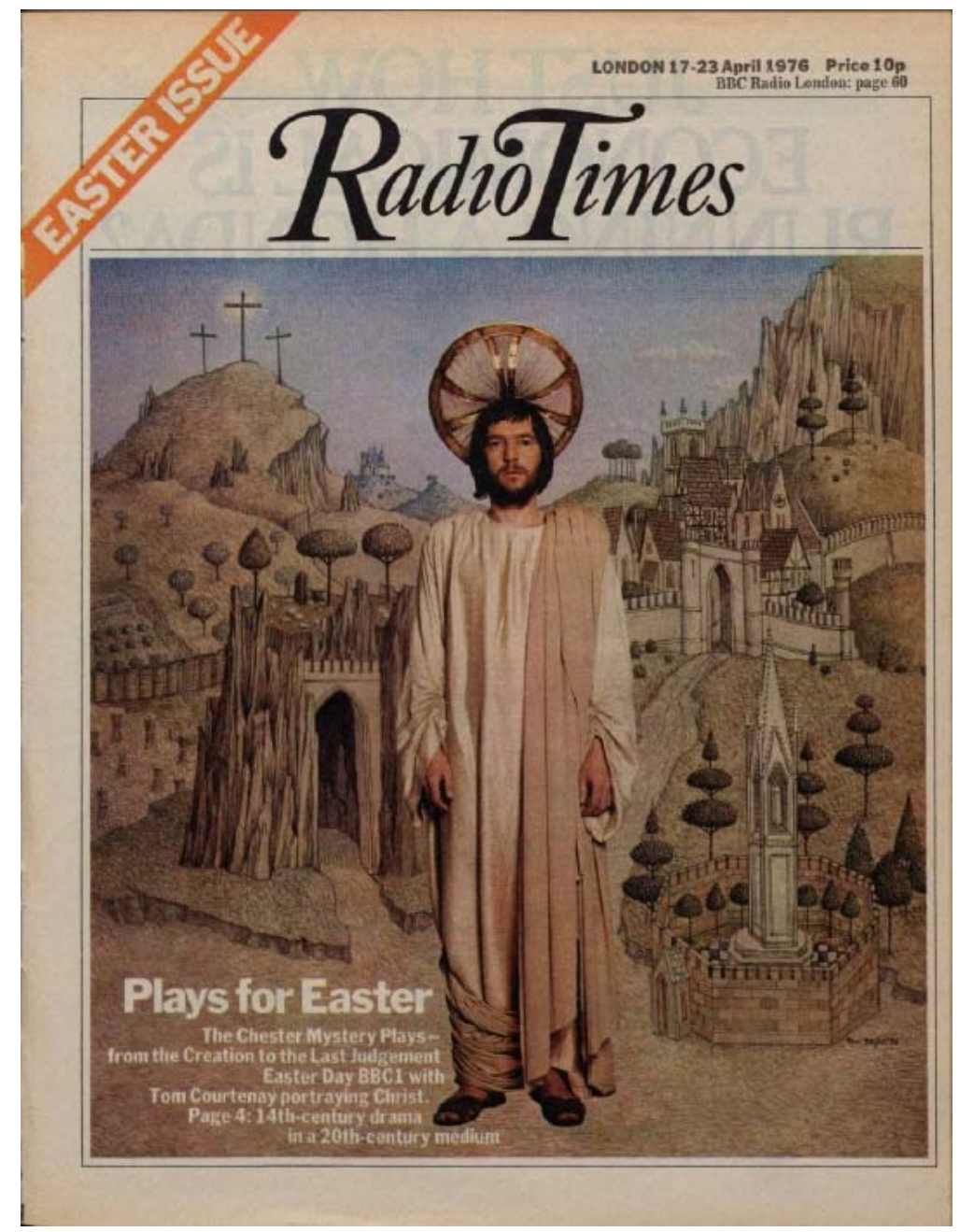

Fig. 2. Tom Courteney as Christ in The Chester Mystery Plays (dir. Piers Haggard, 1976) featured on the front cover of Radio Times, 15 April 1976. Reproduced by permission of Immediate Media.

The article reports that Play of the Month script editor Alan Shallcross, who had seen the 1951 amateur revival of the Chester cycle in Chester Cathedral staged as part of the Festival of Britain celebrations, had wanted to produce the cycle for television but was daunted by the number of difficulties, especially regarding staging: a studio would require a prohibitively expensive number of sets and the streets of Chester were full of traffic and modern buildings. CSO provided the solution: around eighty small paintings, based on illuminated manuscripts such as the Très Riches Heures du Duc de Berry, provided the backgrounds, and the effect "is sometimes like medieval stained glass, with moving figures" (Mitchell 4). In a quotation appended to the Radio Times article, director Piers Haggard stated that, with CSO, "the stories and visual poetry of the plays are freed. If you want an angel in the sky, you have one-because CSO means you can make magic. You can recapture the fantasy, fairy-tale quality of the plays - but the effect is not 'arty,' we hope: we have tried for the graphic clarity and speed of a cartoon" (Mitchell 5). Regional accents, especially from the north of England (this being the Chester cycle), certainly help to ground the performance in this regard. 
Following the opening credits, given in the font and design of an illuminated manuscript, we are introduced to the first scene, "The Fall of Lucifer," by the camera closing in on a circular detail that serves as a "window." The first words of the play, spoken by God, are given in voiceover, as the camera moves slowly closer to another circular illustration, which mixes into yet another circle in which the human, gesticulating figure of God is shown as a small figure seated on his throne high up in the sky, surrounded by drawings of small groups of praying angels, standing on clouds. On his words "Nine orders of angels," the angel drawings are replaced by human actors (of both genders and a wide age-range), who are rather more gaudily attired, looking around and at each other, smiling broadly. After singing a few solemn lines of the "Dignus Dei," God exits (by walking towards camera) and the angels begin to squabble amongst themselves. When God returns to see Lucifer and Lightborne sitting together like children on the oversized throne, a note of comedy is introduced as they are made to fall, wailing, down to Hell-indeed, as if in a cartoon. Gently humorous elements abound, such as when Noah tries to persuade his wife to get out of bed by removing the covers, as do poignant moments, for example, when Abraham's son Isaac willingly kneels so that his father can kill him, and asks him to cover his eyes and talk no longer. The juxtaposition of humor and solemnity, humanity and fantasy, as well as the wonderfully strange combination of the real and the pictorial, is at the heart of this production's achievements.

As Leah Panos has noted recently in an insightful article on CSO in BBC television plays of the 1970s, in The Chester Mystery Plays, "a collaged aesthetic was presented, with characters overlaid onto a pictorially compartmentalized image, rather than appearing within a 3D representation of a room or landscape. [. . . T] $]$ his abstract approach was highly appropriate for the representation of divine spaces and phenomena"(11). The portrayal of God in a variety of different sizes and within different kinds of graphical frame is strikingly effective in giving a sense of this character's omniscience and omnipotence within the story: the actor's body is comparatively the size of a giant when watching a tiny Adam enter the Garden of Eden, but the characters are the same height when talking to each other moments later within the garden; when appearing to Abraham, God's head alone appears high up in the sky, like the sun. "It was a slow, highly technical business, making Chester's local drama available to an audience larger than the population of the whole of medieval England. The guilds bringing it to you are no longer the Barbers, the Blacksmiths, the Bakers and the Fishmongers, but Equity, ACTT, ABS, NATTKE and ETU," wrote Julian Mitchell in his Radio Times article which, in introducing the techniques, the sheer labor and the individuals that made the production work, seeks almost to create a living connection between those individuals whose talent and skills lay behind the production and those viewers at home who received the program on their television sets (5). And those viewers-approximately $4.8 \%$ of the UK's adult population tuned in-were generally favorable towards this unusual Play of the Month offering, as the BBC recorded in its audience research report (compiled from the responses of sixty-five viewers who completed a questionnaire):

Clearly of historical interest to many, it seems a number were also greatly impressed by the simplicity and directness with which episodes in Christ's life were depicted ("uncomplicated, yet full of meaning"), some nonChristians claiming they had been surprisingly moved and absorbed. [. . .] There was also generally enthusiastic approval for the "original," "superbly realistic" production, the colour separation 
overlay technique (CSO) being widely acclaimed as ingenious: "An outstanding presentation deserving all congratulation"; "Tricks effective without becoming obtrusive or mannered"; "Excellent art work." (BBC WAC VR/76/209)

As these responses indicate, The Chester Mystery Plays succeeded in employing sophisticated contemporary technology to reinterpret successfully the central values of the medieval mystery plays for many modern viewers.

\section{Biblical and British Landscapes in Educational Programs}

In contrast to these heavily stylized and high-budget examples stand two studio productions that locate the action of mystery plays within strongly evocative landscapes. In 1961, the rural setting of a BBC Schools production of The Wakefield Shepherds' Play resonated with the landscape of the Pennines, while the 1977 BBCOpen University double-bill production of the Brome Abraham and Isaac and the York Crucifixion drew on an imagined landscape (and dress) of biblical times. At 2.05pm on Tuesday 28 November 1961, a thirty-minute production of The Wakefield Shepherds' Play, adapted and produced by Ronald Eyre, was transmitted as the final program in an eleven-part series titled Drama for BBC Schools (featuring also performances of works such as Sophocles's Philoctetes, Anton Chekhov's The Wedding, and Christopher Marlowe's Doctor Faustus). ${ }^{10}$ The BBC published pamphlets for teachers in association with such series, and the one for Drama offered a four-page essay on this play, including the dramatic tradition of which it formed a part, original performance contexts, the verse, the translation, the plot, and the characters (the pamphlet is titled "BBC School Television Broadcasts: Drama, Autumn 1961," in the BBC WAC). Regarding the staging, the pamphlet merely says that such plays were performed on pageants (described as "a stage on wheels"), noting that "Once outside the church doors, plays eluded some of the severest church censorship" and The Wakefield Master [. . .] put "side by side a knock-about farce and the nativity [. . . . Keeping the tenuous thread of a religious story, the plays absorbed contemporary complaints and reflected contemporary interests (landlords, taxes, war, wives)."

The essay closes with five questions, the first of which is "How do you know that we are in England rather than Palestine?" The fact that the set of this play, which demands an out-of-doors setting for much of the action, evokes the moorland of the Pennines rather than a biblical landscape must surely be understood as a recognition of the attribution of the play to the Wakefield Master. The opening title is superimposed on a close-up of a pair of hands in ragged leather gloves repairing a fence and, as the face of this First Shepherd (played by Dudley Foster) comes into shot, he speaks with a strong northern English accent about his lot, as an unrelenting wind whistles on the soundtrack. Fellow shepherds (Neil McCarthy and Michael Williams) join him and the harshness of their living quarters is laid bare as we observe domestic scenes of cooking, eating and singing within a partially roofed and fenced-off area in a rocky hollow, with a stone wall providing some small relief from the wind. Beyond this, the landscape features a rocky outcrop, leaf-strewn scrubland, bushes, and a stream, all of which are resonant of the British countryside-and, especially, perhaps, the moorland of the Pennines on the eastern edge of which Wakefield is situated. The opening action within such a distinctly familiar landscape is made all the more "British," rather than "biblical", by the 
distinctiveness of the northern accents and expressions (such as "Give over" for "Stop it," and "Ta-ra" for "Goodbye") in Ronald Eyre's adaptation of the original script. There is also a sense of outdoors in the hay-strewn floor and hay-beds of the set representing the humble cottage of Mak (Timothy Bateson), the thief who has stolen one of the shepherds' flock. The shepherds soon locate the sheep, hidden in Mak's newborn baby's cradle, in a farcical scene that prefigures the imminent visit of the shepherds to the baby Jesus in a manger that is represented by a very plain structure with no distinguishing features to indicate either Bethlehem or the Pennines.

In 1977, the Open University, in collaboration with the BBC, produced and transmitted the Brome Abraham and Isaac and the York Crucifixion as a double-bill television program that served as part of the study materials for the undergraduate A307 Drama course and as entertainment for a general, non-student audience. 11 This television program, which was produced by Nick Levinson in Alexandra Palace's relatively small studio A, was part of the course materials for the Medieval English Drama component of the course. Since the A307 Drama course was an annual offering, this program was transmitted each year until 1981. A short spoken introduction to the program is given by the academic Brian Stone as voice-over accompanying two images of stained glass windows depicting, respectively Abraham and Isaac and the Crucifixion. Stone states that "We have not attempted Medieval staging-we have set the plays in biblical times" ("OUP Programme Synopsis"). Accordingly, the camera script indicates an "Arid setting in Palestine" for both plays ("Checked as Broadcast Script"). These "simple stylisations of the biblical landscape" were intended to "help bring out the drama." Rocky outcrops are indicated by large rectangular blocks placed at angles, the "arid setting" is represented by sparse twigs and leafless bushes and the bright blue cyclorama contributes to the sense of a warm location, as do the short-sleeved, "Roman" costumes worn by the soldiers in the second play. Lighting mainly comes from one source to give the sense of the harshness of the sun.

The educational broadcasting contexts of these productions suggest constraints on budget that no doubt dictated such relatively simple design choices, but in each case the use of landscape as setting for mystery plays brings particularly interesting dynamics to the performances. Situating the 1961 BBC Schools production of The Wakefield Shepherds' Play so firmly within the northern English roots of its creation serves to underline its literal geographical provenance; at the same time, the use of sets that emerge from the narrative of the plot (landscapes and agricultural buildings) disengages the play from any social or community resonances connected with its original performance contexts, which, instead, are alluded to in associated printed course materials. Similarly, the Open University-BBC double-bill of the Brome Abraham and Isaac and the York Crucifixion is performed in landscape sets that, relating directly to the biblical stories, draw attention away from medieval, urban, and community-centered performance contexts. The printed course materials in the A307 Medieval English Drama booklet, however, explore the performative social and historical aspects of both plays in great detail, and this is supported by several pages of images and discussion in the related Theatres and Staging booklet.

\section{Bristol Cathedral as Television Studio}


On Maundy Thursday 14 April 1960 (9.45-11.15pm), the BBC broadcast from Bristol Cathedral a performance of The True Mistery of the Passion, a ninety-minute production of James Kirkup's adaptation of the medieval French play Mystère de la Passion by brothers Arnoul and Simon Gréban. This was a joint enterprise between the West of England and the Welsh studios, with designs by Desmond Chinn and music by Reginald Redman. The producer Brandon Acton-Bond outlined in Radio Times this production's relationship with a radio broadcast of the same text that he had coproduced for the Home Service in 1957:

We began thinking of a television production of the play when we were planning it for radio. We were borrowing then from certain television methods to help us solve some new problems in that presentation. However, there still remained many problems to be overcome for television; technically, because of the extreme difficulty of mounting a television drama in a cathedral, in sound coverage, in lighting such a great area, in the building of the three stages, and in the installation of six cameras and their ancillary equipment; artistically, because we intend to present the play as a medieval performance, and the right balance between the unpolished acting on the platforms, which serve as stages, and the demands of the television camera for reality must be satisfying. 12

The 1960 television production, which was recorded, was repeated on Good Friday in the following year (2.45pm, 31 March 1961). This transmission was preceded, on the previous Sunday, by a fifteen-minute documentary titled The Mistery Story: How a Cathedral Became a Television Studio (26 March 1961, 6.45pm), which valuably records some of the practical aspects of the transformation of cathedral into studio, with the narrator George Woodbridge (who had played the Carpenter) noting that the undertaking of a drama production in such a space involved "much more than a big Outside Broadcast." This short program foregrounds the importance of craft and technology, especially lighting, sets and costumes, in a way that resonates cleverly with the contributions of guilds and craftsmen to medieval performances of mystery plays. There is footage of the creation of special galleries for lighting crews and equipment, with lights being hoisted into position and cameras being rolled in. Over images of carpenters at work, Woodbridge explains that three simple sets were intended to give the impression of "the ordinary folk of some country town acting for their neighbors in a setting that fitted their time and circumstance." Against shots of the wardrobe and make-up departments, located in the nearby cathedral school, Woodbridge relates how discussion with English professors, objects from the Jewish Museum, and fifteenth-century paintings enabled a compromise to be reached over the style of dress: "We were supposed to be medieval Englishmen but our story of the passion belonged to the middle east in the time of the Romans." Jocular footage of costumed actors getting off a bus, going into a telephone box and having a cup of tea bring home the practicalities involved. Toward the end of the short documentary, there is an increasing focus on the technology: the viewer observes cameras on dollies, moving both vertically and horizontally to create the shots of the actors, who can also be seen. Coming at the end of the program, such images seem to encourage the viewer to identify with the perspective of the cameraman or director and to engender a sense of excitement in anticipation of this unusual television transmission. 
The production opens with the hubbub of an assembled crowd, with one voice announcing "Hot cross buns!" for sale and another commenting that "It's a proper crowd here today." The camera follows the transport of wooden crosses across the space from a distance, and takes in individuals dancing, performing gymnastics and watching the action, giving a sense of the broader entertainment and celebratory context. From snatches of overheard conversation about who is taking what role, etc., it soon becomes clear that we are not yet in the play proper; rather, this medieval community is about to participate in a mystery play performance, either as observers or as performers. We see a wooden scaffold that raises the performers by about five feet. The production is introduced (with a cheery "Shut up, the lot of you!" address to the crowd) and the camera follows the action from behind the heads of the standing, jostling audience, offering us their visual perspective and eavesdropping on their comments. On the entrance of Judas, for example, one says, "I must be careful what I say; I'm married to his sister!", and the crowd around him laughs. "This table they're bringing on-I made it," says a man as the scene is set for the Last Supper. As the men to be crucified with Jesus are brought in, another says, "That's how we always do our crucifixions. We tie them to the crosses with good strong rope."

This play-within-a-play structure works exceptionally well in this production owing to the expert camerawork, which brings the internal audience in and out of frame regularly and organically, capturing not only their gaze but also their conversations and other responses around the action. The internal audience is rarely forgotten for long but, increasingly as the production progresses, the camera zooms in on the biblical action, losing the community background for longer periods for scenes such as the Last Supper. Writing in The Listener, Irving Wardle admired

the casual atmosphere of a charade gradually contracting into tragic intensity that united the actors and the spectators. Immediately before the crucifixion, the carpenter turned to his companion, his voice shaking with anguish: "They'll be hammering in the nails in a minute-terrible noise that makes"; and when the vast cross was raised into position it broke through the fourth wall, transforming the audience into witnesses at Calvary. 


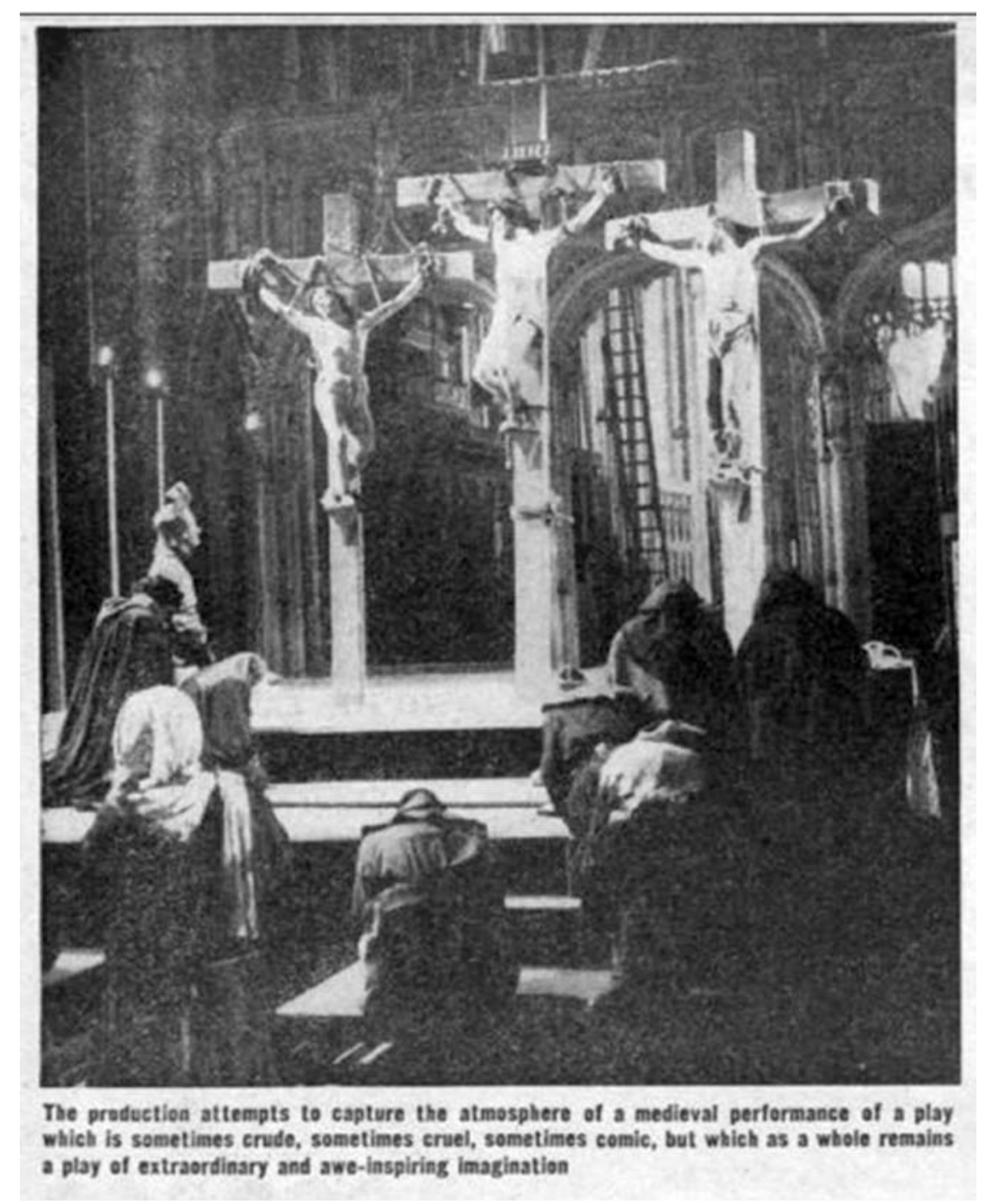

Fig. 3. The crucifixion scene in The True Mistery of the Passion (prod. Brandon Acton-Bond, 1961), printed in Radio Times, 23 March 1961 (54) for a repeat broadcast of the program. Reproduced by permission of Immediate Media.

Mary Crozier in the Guardian agreed that "The crowd of onlookers was part of the scene, following the action from one scene to another, and making their comments, so that the viewer was included among them." What is striking in both of these reviews is the common sense of how the production managed to make the viewer at home feel part of the drama's internal "audience" of medieval villagers. The scene before the cross is said to have "broke[n] through the fourth wall, transforming the audience [at home] into witnesses at Calvary," with the domestic viewer "included among" the "crowd of onlookers," according to these two critics.

The opinions of the seventy-six people from the audience research panel who responded to the BBC's questionnaire on this production resulted in a very good "reaction index" of 74 :

A number of viewers mentioned various specific points in appreciation of its style and performance. An important one, it seems, was the inclusion of an audience ("on stage" in the nave of Bristol Cathedral, which was the setting for the play) 
representing the kind of people who may have watched The True Mistery of the Passion when it was first presented five centuries ago. This was a touch that was said to have helped to recreate a mediaeval atmosphere, and, in the words of a University Lecturer, "greatly enhanced the effect of the play while we, the viewers, could enjoy vicariously being frightened by a Devil who otherwise would have been a mere pantomime demon." (BBC WAC VR/60/210)

One Minister of Religion considered that "It was very cleverly produced. The idea of our 'eavesdropping' on a mediaeval Passion play was very good and unusual. Moreover, it enabled certain difficulties regarding realism to be dealt with allegorically or at least 'theatrically' without losing the realism." Three-quarters of the audience sample "had been deeply moved by the play," which was experienced as "an intensely dramatic and vivid account of the events of the first Easter-in a number of opinions, a more truly natural and therefore more impressive version of the Passion than any seen or heard before." The cathedral setting had been "ideal" for many in the audience: "the presentation [. . .] moved stage by stage at an unhurried pace and with a most effective sense of space in every scene."

The most notable aspect of this production would seem to be its performance in Bristol Cathedral, but this is not made obvious for much of the play. Only at certain points is it emphasized, offering powerful resonances in the Last Supper scene, for example, which is set in such a way that the camera holds the sacramental space of the altar (the place of the consecration of the Eucharist, itself a replaying of the Passover meal over which Jesus is here presiding) clearly lit in the background, when it rests in darkness at other times. What is striking is how easily the large spaces and monumental structure of the cathedral, with clever camerawork and lighting, enable the sense of being in the open spaces of a medieval town. From a letter in the archives written to the adaptor James Kirkup it is apparent that producer Acton-Bond would have much preferred to set the performance in an outdoor marketplace or in a secular building, but various practicalities ruled these options out and the overwhelming welcome offered by the Church authorities made the cathedral a very convenient choice. 13 In order to offset what he felt was "a real danger of the play being turned off by millions of viewers who might expect to find a worthy and dull religious semi-drama," Acton-Bond deliberately played down the presence of the cathedral in most scenes: "one will, I think, be mainly conscious of the screen and the very heavy columns, and by lighting it carefully, although it will inescapably be in part of a place of worship it may seem as likely to belong to the precincts of the building as the building itself." The sophisticated uses of the spaces of the cathedral, together with the contemporary language and the involvement of the viewer as a surrogate member of the medieval audience would appear to have counteracted any concerns felt by viewers in the early 1960s and to have helped achieve a strong sense of relevance for the medieval drama.

\section{Street Theater; or, Theater of Place}

In adapting the mystery plays of Wakefield, York, and Chester for Bill Bryden's promenade productions in the National Theatre's Cottesloe from 1977 to 1985, the Leeds-born poet and playwright Tony Harrison wished "to restore Yorkshire's great classic to itself " (qtd. in Greenhalgh 67). Despite the apparent geographical polarization and possible cultural tension here between place (the north) and space 
(London's Southbank), Harrison's aspiration is observable in the play's representation of the language and working-class culture of the north, with the playwithina-play structure containing a community of workers who put on the mystery plays for the audience of theatre-goers. In an excellent essay on the journey of the three-part The Mysteries from stage to screen, Susanne Greenhalgh traces how the social and industrial unrest of these years became intertwined with their performance at the National, with, for example, the first audiences for The Passion having to cross picket lines to enter the theater, a situation strongly resonant of political tensions in the north and other regions beyond the capital in these years. It was part of the mission of the founding Programme Director of Channel 4, Jeremy Isaacs, to bring large-scale performances of significant works to new audiences and also to represent and serve varied communities. By transmitting The Mysteries to a national audience of around half a million people on 22 and 29 December 1985 (The Nativity and The Passion) and 5 January 1986 (Doomsday), the network was said to have "returned one of the oldest dramatic works of the English language back to its creators-the common people" (Karl Dallas, qtd. in Greenhalgh 82).

In spring 1990, BBC2 broadcast in four parts the Ayrshire-based Borderline Theatre Company's critically acclaimed touring production of Dario Fo's solo Mistero Buffo, with a tour de force performance from Robbie Coltrane. Using the idea of short plays given by medieval traveling performers, this including a presentation of scenes from the life of Christ. A further theater production was transmitted on 6 March 2003 (8.30-10.35pm) when BBC4 carried The Mysteries, a critically acclaimed South African stage musical that had opened in London in 2001. This version of the Chester Mystery Cycle, created by Mark Dornford-May and Charles Hazelwood and performed in English, Afrikaans, Xhosa, and Zulu, was filmed at the Queen's Theatre, London. The cast were mostly amateurs, but the theater production had astounded critics: Charles Spencer, writing in the Telegraph, considered it "one of the most moving, beautiful, humane and courageous shows you will ever see in the West End." Michael Billington, too, admired the production, but his review in the Guardian underlines its relationship with the history and politics of South Africa:

a piece of total theatre in which speech, song and dance harmoniously unite. The cast beat upturned dustbins and oil-drums attached to the boxes. Jesus attracts his followers with a recorder. The post-flood happiness is evoked through You Are My Sunshine and the a cappella choruses raise the roof. But [. . . ] everything is put to the service of an idea: a re-telling of the Christian story in terms of a modern South Africa facing its own desire for truth and reconciliation.

As is also evidenced by the Manchester Passion, considered below, the medieval mystery plays have been interpreted in new contexts in the twenty-first century, and as a consequence they have continued to appeal to television commissioners and to audiences.

Conceived for a much narrower audience and with a more specifically didactic intent, and in contrast to its earlier performative engagement with mystery plays that set them within an abstract biblical landscape, in 1990 The Open University first transmitted a double-bill production of The Annunciation and the comedy Joseph's Trouble about Mary from the York cycle. This was created as one of the television study materials for its undergraduate course A205 Culture and Belief in Europe 
1450-1600, and was staged by The Medieval Players on a small raised pageant set before the Guildhall in Peterborough. The sparse, standing audience appear to have assembled themselves voluntarily before the pageant and the cars and shoppers visible at the edges of the frame give an air of realism to this modern reconstruction of medieval verse and staging on which medieval theater historian Meg Twycross, vastly experienced in recreating medieval street-performance conditions, is credited as Consultant. The twenty-five-minute program was broadcast twice yearly from 1990 to 1999 , surely making it the most frequently televised performance of medieval mystery plays.

Broadcast television's most recent presentation as drama of a spectacle drawn from the medieval theatre was screened on Good Friday 14 April 2006, when BBC Three broadcast live the Manchester Passion. This was an extraordinary street theater production that drew around seven thousand people to the city's Albert Square to watch the performance partly on large screens and partly enacted before them. Keith Allen served as an onstage narrator for the audience in the early part of the play, taking the role of Pontius Pilate once the action moved into Albert Square, a promenade performance dimension that resonates with the National Theatre of Wales's The Passion, performed in Port Talbot at Easter 2011 (which was itself the subject of a two-part BBC documentary). The Manchester Passion was punctuated with segments in which ITV television presenter and journalist Ranvir Singh interviewed audience members, pre-selected to represent several faiths and none, about their reasons for wanting to be part of this performance event. These miniinterviews introduced an unusual sense of immediacy to the production. Most notably, dialogue was minimal and, instead of long spoken scenes, songs from Manchester's rich musical heritage were used to illustrate the story: Joy Division's Love Will Tear Us Apart accompanied the Last Supper scene and the resurrected Christ sang I Am the Resurrection by The Stone Roses from the clock tower of the Town Hall. The choice of music in this program anchored the performance, and the viewers' interpretation of it, in a cultural history that was powerfully specific to place, as Keith Allen underscored in his introduction to the performance:

Tonight, Manchester, founded by the Romans, bombed by the Nazis and the IRA, home to the Buzzcocks, Take That, and-heaven forbid-the Bee Gees, will host the Passion: the story and pictures, words and music, of the final hours of Jesus Christ, from the Last Supper to this Crucifixion, as told in the Gospels in the New Testament. The streets of the city will be our Jerusalem, and the music is Manchester-based music from Oasis to M People, from Joy Division to the Happy Mondays. The sacred and the profane together, as you've never heard them before.

As is demonstrated by the Manchester Passion, television in the twentyfirst century continues to be engaged with the medieval mystery plays. It would appear that in contrast with many other kinds of theater these dramas will continue to be reinvented and reimagined by future forms of the medium.

\section{Conclusion}

Over the course of the twentieth century and into the twenty-first, British television has explored the relevance of mystery play performance both to the medieval world and to contemporary life in Britain. A series of interpretative lenses appear to have 
emphasized time and place above all, with an increasing focus on immediacy, geographically specific places, and localized communities around the turn of the century. In the last three decades, television would seem to have lost interest in mounting studio (or other indoor) productions of mystery plays; instead, the focus has shifted to making programs that convey something of the theatricality and the liveness of performative engagements with the plays that are embedded in particular localities and communities. Following the turn of the millennium, mystery play performances on television have become even more strongly embedded in particular localities and communities, with interest especially focused on performance as event (for example, the 2006 the Manchester Passion was anchored powerfully in the open spaces of the city and its famous musical history) or even as kind of "reality TV" experiment (see, for example, the social realities underlying the drawing together of community in the making of a mystery play film in the 2008 Miracle on the Estate).

Earlier productions demonstrate a keen awareness of how spaces of production resonate with particular times and places-and, in some instances, with the communities of these times and places. The degree to which these productions were concerned with contributing an understanding of mystery plays as a medieval mode of expression relating to religious, social, and civic traditions and community life very much depended on the commission behind a particular production and, within those constraints, individual directorial vision. Thus both the 1961 BBC Schools production and the 1977 Open University double bill utilized relatively inexpensive landscape settings, safe in the knowledge that detailed information on the debates surrounding the original performance conditions would be conveyed in accompanying print resources.

Several productions used settings that strongly evoke the visual imagery of medieval art and artefacts, from stained-glass window compositions to illuminated manuscripts. The intention behind the stylization of the 1947 and 1949 studio productions, for example, appears to have been to make the plays approachable via other, roughly chronological, cultural forms with strong religious and visual dimensions, even if the visual arts being referenced had no direct relationship with mystery play performance. In 1976, the technique of CSO enabled medieval art to be used not merely as the frame but also as the aesthetic and compositional backbone of The Chester Mystery Plays in a highly inventive and striking way. Although the paintings forming the visual background of the production were based on medieval art, some of the effects of CSO introduced a wonderfully fantastical, other-worldly space that, in its entirety, could exist nowhere else but on screen. The use of CSO created a production that, of all the examples discussed here, is the one least tied to a particular time and place (and therefore has little connection with a specific community or performance conditions).

By contrast, the 1960 production of The True Mistery of the Passion manages to construct a rich and vivid sense both of medieval place and community. Camerawork and lighting ensured that the large spaces and monumental structure of Bristol Cathedral suggested the open spaces of a medieval town rather than a contemporary place of worship, and the cameras also served the play-within-a-play structure by bringing the internal audience in and out of frame regularly and organically, capturing not only their gaze but also their chatter about the play production they were watching. The True Mistery offers a strong depiction of 
medieval space, place, and community; a sense of civic, social, and religious tradition (including play performance); and a suggestion of the continuing relevance of these medieval performance texts in the modern world (through modern speech and occasional reference to the Cathedral setting). The BBC concluded from its audience research exercise that this television production had been "a more truly natural and therefore more impressive version of the Passion than any seen or heard before" (BBC WAC VR/60/2010)—and, perhaps, we might say, since.

\section{Notes}

${ }^{1}$ Corpus Christi, a Roman Catholic feast celebrated also by the Church of England, was the occasion for the performance of mystery plays in medieval times.

2 See the Screen Plays database, hosted by the BUFVC, for production data.

3On the production history of Greek drama on British television, see Wrigley "Space," "Greek," and Greece, for example.

4Two outstanding examples are the essays by Susanne Greenhalgh and Leah Panos who discuss, respectively, the National Theatre's production of The Mysteries on Channel 4 in 1985-86 and the use of the Colour Separation Overlay technique in the 1976 BBC production of The Chester Mystery Plays.

5The script was compiled from the Everyman edition. Barry Learoyd's 1947 sets were replaced by new ones by Richard Greenough; similarly, Charlotte Bidmead, responsible for movement in 1947, was replaced by the ballerina Lydia Sokolova.

6Transmitted on 17 June 1947 and 9 November 1947 respectively (BBC WAC T5/114).

7The first page is titled "The Coventry Nativity Play, adapted and produced by Douglas Allen," suggesting that it belonged to him, supported by the fact that it is a kind of handwritten camera script notebook. The actors' names written by the list of parts suggest it may have dated from 1947.

8This at least was the planned wording (memo from Douglas Allen to Mr Rawes, 20 December 1949, in BBC WAC T5/114). Junior-age schoolchildren heard an adaptation of this same nativity play by Moira Doolan broadcast "for the schools" on the Home Service on 7 December 1949. In this respect, it should be remembered that this first, full performative engagement of television with mystery plays may be considered a novelty or an experiment in form, but in terms of broadcasting more broadly it is a natural progression from over two decades' worth of BBC radio performances with mystery plays.

9Memo from George More O'Ferrall to Television Programme Director, 12 December 1947 (BBC WAC T5/114). As a senior producer, O'Ferrall had been asked to keep "a friendly eye" on the production in the lead up to transmission 
(memo from Television Programme Director to Douglas Allen and George More O’Ferrall, 4 November 1947, BBC WAC T5/114.).

10Radio Times billed it as The Wakefield Shepherds' Play; the recording of the program in the BBC archive uses Wakefield: The Shepherds' Play as the opening title; in the pamphlet for schools produced for schools by the BBC, it is titled The Second Shepherd's Play from the Wakefield Cycle. On Philoctetes and drama for schools more generally, see Wrigley ("Greek Tragedy").

11On the use of television as a teaching tool in The Open University's courses on drama, see Wrigley ("Higher Education").

${ }^{12}$ The True Mistery of the Passion was first performed on radio in a production by Martin Willson and Brandon Acton-Bond, with music specially composed by Reginald Redman (9.15pm, 18 April 1957, Home Service, where it was repeated at 9.15pm on 3 April 1958). The audience research report indicates that many listeners found it almost unbearably moving (BBC WAC LR/57/654).

13Letter from Acton-Bond to Kirkup, 25 January 1960 (BBC WAC, WE23/26).

\section{Works Cited}

Abraham and Isaac / The Crucifixion. Prod. Nick Levinson. The Open University / BBC. 20 Mar. 1977. Television.

Acton-Bond, Brandon. "The True Mistery of the Passion." Radio Times 8 Apr. 1960: 15. Print.

The Annunciation and Joseph's Trouble about Mary (double bill). BBC / The Open University / The Medieval Players. Transmitted annually, 1990-99. Television. BBC Written Archives Centre (WAC). Archive file for Coventry Nativity Play. 1947-49. TS. T5/114. BBC Written Archives Centre, Reading.

Audience Research Report. 8 May 1957. TS. LR/57/654. BBC Written Archives Centre, Reading.

Audience Research Report. 13 May 1960. TS. VR/60/210. BBC Written Archives Centre, Reading.

Audience Research Report. 13 May 1976. TS. VR/76/209. BBC Written Archives Centre, Reading.

Archive File for James Kirkup. 1960-71. TS. WE23/26. BBC Written Archives Centre, Reading.

Beadle, Richard and Alan J. Fletcher, ed.. The Cambridge Companion to Medieval English Theatre. 2nd ed. Cambridge: Cambridge UP, 2008. Print.

Billington, Michael. “The Mysteries, Queen's Theatre, London.” Guardian. Guardian 
News and Media, 27 Feb. 2002. Web. 24 Feb. 2015. "Checked as Broadcast Script, A307/03, Recorded: studio 1st-4th June 1976." N.d. TS. The Open University Archive, Milton Keynes.

The Chester Mystery Plays. Dir. Piers Haggard. BBC. 18 Apr. 1976. Television. The

Coventry Nativity Play. Prod. Douglas Allen. BBC. 24 Dec. 1947. Television. The

Coventry Nativity Play. Prod. Douglas Allen. BBC. 24 Dec. 1949. Television.

Crozier, Mary. "Television." Guardian 16 Apr. 1960: 3. Print.

Dillon, Janette. The Cambridge Introduction to Early English Theatre. Cambridge: Cambridge UP, 2006. Print.

Elliott, John R. Playing God: Medieval Mysteries on the Modern Stage. Toronto: U of Toronto P, 1989. Print.

Greenhalgh, Susanne. "The Mysteries at the National Theatre and Channel Four: Popular Theatre into Popular Television." Boxed Sets: Television Representations of Theatre. Ed. Jeremy Ridgman. Luton: U of Luton P, 1998. 63-88. Print.

Happé, Peter. "A Guide to Criticism of Medieval English Theatre.” The Cambridge Companion to Medieval English Theatre. Ed. Richard Beadle and Alan

J. Fletcher. 2nd ed. Cambridge: Cambridge UP, 2008. 326-60. Print.

Johnston, Alexandra F. "An Introduction to Medieval English Theatre." The Cambridge Companion to Medieval English Theatre. Ed. Richard Beadle and Alan J. Fletcher. 2nd ed. Cambridge: Cambridge UP, 2008. 1-25. Print.

- "The Communities of the York Plays." The York Mystery Plays: Performance in the City. Ed. Margaret Rogerson. Woodbridge: York Medieval, 2011. 157-64. Print.

Manchester Passion. Dir. Phil Chilvers. BBC. 14 Apr. 2006. Television.

McKinnell, John. "Modern Productions of Medieval English Drama." The Cambridge Companion to Medieval English Theatre. Ed. Richard Beadle and Alan J. Fletcher. 2nd ed. Cambridge: Cambridge UP, 2008. 287-325. Print.

Miracle at Chester. Prod. Moultrie R. Kelsall. BBC. 12 Jun. 1938. Television. Miracle on the Estate. Dir. Chris Salt. BBC. 21 Mar. 2008. Television.

Mistero Buffo. Dir. Don Coutts. BBC / Borderline Theatre Company. 5 Apr. 1990. Television.

The Mistery Story: How a Cathedral Became a Television Studio. Prod. Laurie 
Mason. BBC. 26 Mar. 1961. Television.

Mitchell, Julian. "The Word Made Flesh." Radio Times 15 Apr. 1976: 3-5. Print. The Mysteries (Doomsday). Dir. Bill Bryden (stage) and Derek Bailey (screen).

Landseer Productions / National Theatre / Channel 4. 5 Jan. 1986. Television. The Mysteries (The Nativity). Dir. Bill Bryden (stage) and Derek Bailey (screen).

Landseer Productions / National Theatre / Channel 4. 22 Dec. 1985. Television. The Mysteries (The Passion). Dir. Bill Bryden (stage) and Derek Bailey (screen).

Landseer Productions / National Theatre / Channel 4. 29 Dec. 1985. Television. The Mysteries. Dir. Mark Dornford-May. BBC / Dimpho Di Kopane Company. 6 Mar. 2003. Television.

Normington, Katie. Modern Mysteries: Contemporary Productions of Medieval English Cycle Dramas. Cambridge: Brewer, 2007. Print.

The Open University. Theatres and Staging. London: Open UP, 1977. Print.

"OUP Programme Synopsis for A307/03." 8 Nov. 1976. TS. The Open University Archive, Milton Keynes.

Panos, Leah. "Stylised Worlds: Colour Separation Overlay in BBC Television Plays of the 1970s." Critical Studies in Television 8.3 (2013): 1-17. Print.

Rogerson, Margaret. "Introduction: Performance in the City." The York Mystery Plays: Performance in the City. Ed. Margaret Rogerson. Woodbridge: York Medieval, 2011. 1-23. Print.

Spencer, Charles. "Divine, Defiant and Dazzling." Telegraph. Telegraph Media Group, 28 Feb. 2002. Web. 24 Feb. 2015.

Swift, John. "Scriptwriters in Medieval Drama." Radio Times 19 Dec. 1947: 35. Print.

“Television Listings." Radio Times. 10 Jun. 1938: 18. Print.

The True Mistery of the Passion. Prod. Brandon Acton-Bond. BBC. 14 Apr. 1960. Television.

Twycross, Meg. "The Theatricality of Medieval English Plays." The Cambridge Companion to Medieval English Theatre. Ed. Richard Beadle and Alan J. Fletcher. 2nd ed. Cambridge: Cambridge UP, 2008. 26-74. Print.

The Wakefield Shepherds' Play. Prod. Ronald Eyre. BBC. 28 Nov. 1961. Television. Wardle, Irving. "Drama: A Noble Piece.” The Listener 21 Apr. 1960: 726. Print.

Wiles, David. A Short History of Western Performance Space. Cambridge: Cambridge UP, 2003. Print. 
Wrigley, Amanda. "Space and Place in Joan Kemp-Welch's Television Productions of Theatre Plays." Historical Journal of Film, Radio and Television 34.3 (2014): 40519. Print.

- "Greek Tragedy in the BBC and ITV Schools Television Curricula of the 1960s." Ancient Greece on British Television. Ed. Fiona Hobden and Amanda Wrigley. Edinburgh: Edinburgh UP, 2017. Forthcoming.

—. "Higher Education, Public Engagement: BBC-Open University Coproductions of Drama on BBC2 in the 1970s." Journal of British Cinema and Television 13.3 (2017): forthcoming.

Greece on Screen: Greek Plays on British Television. 2017. Forthcoming. 